\title{
ПОДОЛАННЯ ТИСКУ НА УЧАСНИКІВ КРИМІНАЛЬНОГО ПРОВАДЖЕННЯ ПІД ЧАС СУДОВОГО РОЗГЛЯДУ
}

\author{
Одерій О. В., Мудрецький Р. В.
}

\section{ВСТУП}

Суб'єкти протидії судовому розгляду кримінальних проваджень використовують різні заходи, пов'язані з погрозами на адресу певних осіб, які $є$ учасниками кримінального провадження, та реальним фізичним впливом (насильством) на них. Найбільш активна протидія правосуддю виявляється з боку осіб, зацікавлених у вирішенні справи, що ставить під загрозу iї справедливий розгляд, гарантований ст. 21 Кримінального процесуального кодексу (далі - КПК) України. Більше того, окремі науковці прямо зазначають, що сильний тиск на свідків обвинувачення та потерпілих фіксується в ході розслідування практично всіх кримінальних проваджень, особливо з боку представників організованої групи $(98 \%)^{1}$. Нині такі прийоми протидії $\epsilon$ поширеним явищем. Їх застосуванню сприяють правова й економічна ситуація в країні, яка характеризується обмеженими можливостями правоохоронних органів щодо захисту як потерпілих, свідків, їхніх близьких, так і майна від загрози з боку організованих злочинних груп ${ }^{2}$. Протиправний вплив на осіб, котрі сприяють кримінальному судочинству, фактично $\epsilon$ засобом підриву правосуддя ${ }^{3}$.

За результатами проведеного нами анкетування суддів, захисників i працівників правоохоронних органів можна констатувати, що у своїй практичній діяльності вони зіштовхувалися 3 різноманітними формами насильницького впливу на учасників кримінального провадження. Зокрема: а) на інтелектуальний спосіб протидії (психічне насильство) вказали 58\% опитаних; б) на фізичний (фізичне насильство) або вбивство учасників кримінального провадження - 32\%; в) на економічний (підкуп) $30 \%$. Вплив був переважно спрямований на свідків і потерпілих $-45 \%$ і $50 \%$ відповідно. Крім того, 25\% опитаних окремо виділили протидію, яка

\footnotetext{
${ }^{1}$ Трухачев В.В. Криминалистический анализ сокрытия преступной деятельности. Воронеж : Изд-во Воронеж. гос. ун-та, 2000. С. 196.

2 Біленчук П.Д., Луговий І.О. Способи протидії злочинних угруповань діяльності правоохоронних органів у розслідуванні злочинів. Науковий вісник Нац. акад. внутр. справ Украйни. 2003. № 1. С. 196.

${ }^{3}$ Новикова М.В. Обеспечение безопасности участников уголовного судопроизводства как гарантия осуществления правосудия в современных условиях : автореф. дис. ... канд. юрид. наук : 12.00.09. Екатеринбург, 2006. С. 21.
} 
чиниться з боку захисника обвинуваченого у провадженні, а $15 \%$ - $з$ боку працівників правоохоронних органів у вигляді здійснення недозволених методів розслідування. У зв'язку з цим працівникам правоохоронних органів і суду було поставлене додаткове питання: «Чи потребуєте ви захисту з боку держави?», на яке $100 \%$ однозначно відповіли: «Так». Це, хоча й побічно, але свідчить про масовий характер протидії. Тому, перш ніж вимагати від свідків, потерпілих, експертів і перекладачів співпраці $з$ правоохоронними органами, держава має забезпечити їм належний рівень захисту, оскільки, як слушно зауважують Н.С. Карпов та О.I. Габро, головною причиною збільшення кількості завідомо неправдивих показань, висновків, перекладів або відмови від давання показань $\epsilon$ саме незахищеність цих суб'єктів кримінально-правових (кримінальнопроцесуальних) відносин від протиправних дій із боку обвинувачених чи інших зацікавлених осіб ${ }^{4}$. Отже, обрана нами тема дослідження $€$ актуальною та малодослідженою. Метою цієї роботи $є$ дослідження особливостей подолання тиску на учасників кримінального провадження під час судового розгляду; аналіз складників системи протидії в частині подолання тиску на учасників кримінального судочинства; визначення шляхів оптимізації заходів, що застосовуються з метою подолання тиску на учасників кримінального провадження.

\section{1. Тиск на учасників кримінального провадження (поняття, сутність)}

Аналіз наукової літератури дозволяє говорити про відсутність комплексного дослідження подолання тиску на учасників кримінального провадження. Переважно це питання розглядалося як один з елементів протидії на стадії досудового розслідування та не охоплювало стадію судового розгляду. Таке становище $\epsilon$ неприйнятним, тим паче, що сучасними науковцями прямо виокремлюються заходи забезпечення безпеки учасників кримінального судочинства, які застосовують у судових cmadiяx (виділено нами - O. О., Р. М.) кримінального процесу ${ }^{5}$.

Окремі теоретичні та практичні аспекти застосування заходів безпеки щодо учасників кримінального провадження розглядалися в роботах вітчизняних i зарубіжних вчених В.П. Бахіна, В.І. Боярова, Л.В. Брусніцина, В.К. Весельського, О.А. Зайцева, В.С. Зеленецького, Н.С. Карпова, М.В. Куркіна, В.В. Ліпинського, Л.М. Лобойка,

\footnotetext{
${ }^{4}$ Габро O.І., Карпов Н.С. Державний захист та забезпечення безпеки осіб, які беруть участь у судочинстві, за законодавством України. Боротьба з організованою злочинністю $і$ корупщією (теорія $i$ практика) / Міжвідомчий науково-дослідний центр з проблем боротьби з організованою злочинністю. Київ, 2007. № 17. С. 256.

${ }^{5}$ Озерський І.В. Кримінальний процес України : навчальний посібник / Міністерство освіти і науки України. Київ : МАУП, 2003. С. 81.
} 
Є.І. Макаренка, С.Л. Марченка, О.О. Подобного, О.В. Рохненка, Р.В. Тарасенка, В.М. Тертишника, Л.М. Шестопалова, А.Г. Шияна, А.О. Шульги та ін. Однак, незважаючи на актуальність та увагу науковців до зазначеної теми, розгляд питання в аспекті подолання тиску на учасників кримінального провадження під час здійснення його судового розгляду не охоплює всю повноту проблеми, а забезпечення лише безпеки осіб не відображає весь спектр заходів щодо його подолання.

Досліджуючи питання подолання впливу на учасників кримінального провадження, доречно з'ясувати значення поняття «тиск». Академічний тлумачний словник української мови визначає поняття «тиску» як рішучу, енергійну дію, рух, спрямовані на кого-, що-небудь; стрімкий натиск, напад, насильство над чиєюсь волею, переконанням; примус ${ }^{6}$. Оскільки в питанні, що нами досліджується, говориться про способи протидії судовому розгляду кримінальних проваджень, завдяки яким особи, котрі їх застосовують, намагаються вплинути на волю учасників кримінального провадження, зосередимо свою увагу саме на подоланні тиску (виділено нами - $O$. $O$., P. M.) на них, використовуючи зазначений термін. Таким чином, здійснення тиску зацікавленими особами на свідків, потерпілих та інших учасників кримінального судочинства не лише спрямоване на заподіяння останнім будь-якої шкоди, а й грунтується на досягненні головної мети - схилити їх до відмови давати показання або іншим чином завадити, припинити сприяння правосуддю чи помститися за вже здійснене сприяння. Вплив може бути вираженим у різних формах, але головним чинником виступає мета, з якою він здійснюється ${ }^{7}$. Тобто, здійснення тиску передбачає активну поведінку та вплив зацікавлених осіб безпосередньо на особу як носія інформації про кримінальне правопорушення 3 метою зміни інформації про характер, обставини й учасників злочину, а саме: а) заподіяння або погроза заподіяння матеріального збитку (підпал майна, квартири тощо); б) тероризування рідних або близьких людей; в) вплив на психіку людини та знищення інформації, яка знаходиться у пам'яті людини, знищення, руйнування нейронів пам'яті за допомогою електрошоку, ультразвуку, інших засобів; г) вбивство осіб - носіїв доказової інформації як найбільш небезпечна форма впливу.

Що стосується кола суб'єктів, на яких може бути спрямований тиск під час судового розгляду, то до нього належать будь-які учасники кримінального провадження, визначені Законом (п. 19, 25, 26 ст. 3 КПК

\footnotetext{
${ }^{6}$ Академічний тлумачний словник української мови. URL: http://sum.in.ua/s/tysk.

7 Габро O.I., Карпов Н.С. Державний захист та забезпечення безпеки осіб, які беруть участь у судочинстві, за законодавством України. Боротьба з організованою злочинністю $i$ корупиією(теорія $i$ практика) / Міжвідомчий науково-дослідний центр з проблем боротьби з організованою злочинністю. Київ, 2007. № 17. С. 259.
} 
України) незалежно від їх процесуального статусу. Так, забезпечення безпеки підозрюваному й обвинуваченому у кримінальному провадженні (особливо тим особам, що співпрацюють зі слідством) є вкрай актуальним питанням. Наочними прикладами цьому є вбивство бізнесмена Максима Курочкіна, який, хоча і перебував під вартою, був убитий снайпером на виході з приміщення Святошинського районного суду міста Києва, а також справа перевертнів у погонах Гончарова - Нестерова, де завдяки свідченням останнього стало можливе розкриття великої кількості резонансних вбивств, вчинених працівниками міліції ${ }^{8}$. Не випадково на необхідність захисту осіб, які співпрацюють із правосуддям, як окремої категорії осіб, що потребують забезпечення безпеки, вказується і в міжнародних нормативних актах, зокрема у п. 22 Рекомендації Rec (2005) 9 Комітету міністрів Ради Свропи державам-членам щодо захисту свідків та осіб, які співпрацюють із правосуддям ${ }^{9}$.

Актуальним $€$ й питання подолання тиску на захисника як сторону кримінального провадження. Зокрема, резонансні вбивства адвокатів Юрія Грабовського та Ірини Ноздровської пов'язують саме з їх професійною діяльністю ${ }^{10}$. Відповідно до ч. 2 ст. 5 Закону України «Про адвокатуру і адвокатську діяльність» держава створює належні умови для діяльності адвокатури та забезпечує дотримання гарантій адвокатської діяльності. Ст. 23 цього ж Закону державою гарантується право на забезпечення безпеки адвоката під час участі у кримінальному судочинстві. Крім того, передбачена відповідальність і за незаконні дії щодо захисника у вигляді втручання у його діяльність і насильницькі дії щодо нього та його майна (ст. 397-400 Кримінального кодексу України).

Об'єктивний, справедливий розгляд кримінального провадження та прийняття судом обгрунтованого рішення залежить не тільки від пояснень підозрюваних, обвинувачених, свідків, потерпілих, висновків експертів, а також від дій i рішень слідчого та прокурора, які $\epsilon$ стороною кримінального провадження (п. 19 ст. 3 КПК України). Зазначені особи мають неабиякий вплив на формування доказової бази у справі як об'єкт дослідження та порядок розгляду кримінального провадження. За таких обставин не менш актуальним є питання подолання тиску на вказаних осіб як учасників кримінального провадження. Так, у Костянтинівському

\footnotetext{
8 Дело милицейских оборотней. Газета «Правда». URL: https://www.pravda.com.ua/articles/2007/03/ 28/3220974/; https://racurs.ua/259-miliceyskie-oborotney-delo.html.

${ }_{9}$ Рекомендація Rec (2005) 9 Комітету міністрів Ради Європи державам-членам щодо захисту свідків та осіб, які співпрацюють 3 правосуддям. URL: http:/scourt.gov.ua/clients/vsu/vsu.nsf/(documents)/ 7442A47EB0B374B9C2257D8700495F8B.

10 Бортик. Убивство адвоката. URL: https:/uiamp.org.ua/bortnik-ubiystvo-advokata-grabovskogopoliticheskoe; $\quad$ https://www.unian.net/society/10197798-svetit-pozhiznennoe-podozrevaemomu-v-ubiystveadvokata-nozdrovskoy-izmeneno-ranee-obyavlennoe-podozrenie.html.
} 
міськрайонному суді Донецької області мав місце випадок забезпечення заходами безпеки прокурора, що підтримував обвинувачення в суді у справі № 1-93/2007, оскільки він під час судового розгляду отримав відкриту погрозу на свою адресу від обвинуваченого, котрий тримався під вартою. Через декілька днів обвинувачений здійснив втечу з-під варти, а зазначена погроза була розцінена як реальна ${ }^{11}$.

Аналіз наукових досліджень щодо розробки засобів і методів подолання протидії (у т. ч. й на стадії досудового розслідування) дозволяють констатувати, що у питанні визначення переліку (комплексу) таких заходів єдиного розуміння не досягнуто. Певні науковці дотримуються позиції, згідно з якою до нього належать такі заходи: а) кримінально-правові; б) кримінально-процесуальні (здійснюються під час проведення слідчим тактичних прийомів); в) непроцесуальні; г) оперативно-розшукові; д) сукупність організаційних заходів ${ }^{12}$. Інші вважають, що ними $є$ правові, тактичні, організаційні та заходи попередження ${ }^{13} .3$ наведеного можна дійти висновку, що у системі протидії в частині подолання тиску на учасників кримінального судочинства (окрім кримінально-правових i кримінально-процесуальних заходів, передбачених кримінальнопроцесуальним і законом про кримінальну відповідальність ${ }^{14}$ ) доцільно виокремити позапроцесуальні (організаційно-тактичні) заходи, які регламентовані спеціальними нормативно-правовими актами. Наявність позапроцесуальних заходів визначається також особливим характером їх застосування, наприклад, стосовно забезпечення безпеки учасників кримінального провадження, що зокрема, передбачає: а) здійснення оперативно-розшукових заходів; б) особливий склад осіб, якими приймається рішення про їх застосування та реалізацію; в) здійснення таких заходів за межами кримінального провадження, що перебуває на розгляді в суді. Про існування позапроцесуальних заходів безпеки, які здійснюються за рішенням слідчого, прокурора, слідчого судді чи суду за межами кримінального процесу, згадують В.В. Касько й А.М. Орлеан ${ }^{15}$. Розглянемо зазначені заходи більш детально.

\footnotetext{
11 Із досвіду практичної діяльності Р.В. Мудрецького на посаді судді Костянтинівського міськрайонного суду Донецької області. Власний архів Р.В. Мудрецького.

12 Бабаева Э.У. Противодействие предварительному расследованию и пути его преодоления. Москва : Щит-М, 2001. С. 101-104.

13 Александренко О.В. Криміналістичні проблеми подолання протидії розслідуванню : автореф. дис. ... канд. юрид. наук : 12.00.09. Київ, 2004. С. 14-16.

i4 Александренко О.В. Криміналістичні проблеми подолання протидії розслідуванню : дис. ... канд. юрид. наук : 12.00.09. Київ, 2004. С. 101-104.

15 Касько В.В., Орлеан А.М. Забезпечення безпеки учасників кримінального провадження щодо торгівлі людьми. Київ : «ВАІТЕ», 2012. С. 22.
} 


\section{2. Кримінально-правові та кримінально-процесуальні заходи} подолання тиску на учасників кримінального провадження

Кримінально-правові заходи відіграють важливу роль у припиненні, усуненні та нейтралізації протидії та, будучи закріпленими у нормах кримінального права, надають їм системного, загальнообов'язкового характеру. Вони закріплюють ознаки складу конкретних злочинних діянь, які по суті є різними видами (формами) протидії, і визначають об'єктивну сторону цього діяння, суб'єкта і суб'єктивну сторону ${ }^{16}$.

Враховуючи, що протидіючі суб'єкти застосовують різні форми насильства, яке $є$ фізичним (тілесні ушкодження, побої тощо) або психічним (погроза) впливом одного суб'єкта на іншого ${ }^{17}$, за такі протиправні дії передбачено кримінальну відповідальність. Також Кримінальним Кодексом (далі - КК) України передбачено декілька норм, якими встановлено відповідальність за вчинення злочинного впливу на працівників правоохоронних органів як за злочини проти авторитету органів державної влади. Проте через невизначеність поняття «вплив» у ст. 343 КК України існує ймовірність його широкого тлумачення, тому доцільно передбачити відповідальність за примушування працівника правоохоронного органу шляхом умовляння, погроз, шантажу чи інших неправомірних дій до винесення необгрунтованого, незаконного рішення у кримінальному проваджені. Зазначені дії з боку посадових осіб повинні передбачати більш сувору відповідальність ${ }^{18}$. У свою чергу, на необхідність попередження і викриття протидії з боку посадових осіб, котрі беруть участь у кримінальному провадженні, законодавець відреагував встановленням кримінальної відповідальності за злочини проти правосуддя у розділі XVIII КК України.

Кримінальна відповідальність передбачена і щодо осіб, які зобов'язані сприяти здійсненню правосуддя, зокрема: а) за завідомо неправдиве повідомлення про вчинення злочину та завідомо неправдиве показання; б) відмову свідка від давання показань або відмову експерта чи перекладача від виконання покладених на них обов'язків; в) перешкоджання з'явленню свідка, потерпілого, експерта, примушування їх до відмови від давання показань чи висновку; г) приховування злочину (ст. 383-386, 396 КК України). Наявність кримінальної відповідальності за завідомо неправдиве повідомлення про вчинення злочину покликане

\footnotetext{
16 Бабаева Э.У. Проблемы теории и практики преодоления противодействия уголовному преследованию : монография. Москва : Юрлитинформ, 2010. С. 257.

17 Большой энциклопедический словарь / гл. ред. А.М. Прохоров. Москва : Большая Российская энциклопедия; Сантк-Петербург : Норинт, 1998. С. 785.

18 Александренко О.В. Криміналістичні проблеми подолання протидії розслідуванню : дис. .... канд. юрид. наук : 12.00.09. Київ, 2004. С. 88.
} 
стримувати заявника від зловживання правом на звернення до правоохоронних органів і бажання в межах кримінального провадження вирішити свої цивільно-правові та інші інтереси, де закон не передбачає кримінально-правової відповідальності. Водночас із метою досягнення більш ефективного результату у питанні подолання протидії судовому розгляду кримінальних проваджень доцільно внести певні зміни до КК України. Так, недосконалість правової конструкції ст. 67 КК України «Обставини, що обтяжують покарання» полягає в тому, що в переліку підстав для посилення кримінальної відповідальності відсутнє здійснення протидії розслідуванню та судовому розгляду підозрюваним i обвинуваченим. Саме тому слід погодитися $з$ думкою науковців про те, що протидія розслідуванню та судовому розгляду повинна визнаватися обставиною, яка обтяжує відповідальність ${ }^{19}$, і надати законодавче визначення цьому явищу.

Кримінально-процесуальні заходи подолання тиску на учасників кримінального судочинства регламентуються процесуальними нормами, що передбачають застосування: а) заходів забезпечення кримінального провадження; б) інших процесуальних заходів у межах цього ж кримінального провадження, які передбачають особливий порядок його провадження чи особливий порядок вчинення окремих процесуальних дій для забезпечення подолання тиску на учасників кримінального провадження.

Відповідно до ч. 1 ст. 131 КПК України заходи забезпечення кримінального провадження застосовуються 3 метою досягнення дієвості цього провадження. Вони трактуються як засоби, спрямовані на забезпечення провадження у кримінальних справах, що встановлюють правила поведінки і порядок реалізації учасниками кримінального процесу своїх прав і обов'язків ${ }^{20}$ i містять норми, безпосередньо спрямовані на попередження і подолання протидії.

Заходи забезпечення кримінального провадження у науковій літературі поділяють на: 1) запобіжні заходи (особисте зобов'язання; особиста порука; застава; домашній арешт; тримання під вартою; тимчасовий запобіжний захід у вигляді затримання особи); 2) інші заходи забезпечення кримінального провадження (виклик слідчим, прокурором, судовий виклик і привід; накладення грошового стягнення; тимчасове обмеження в користуванні спеціальним правом; відсторонення від посади; тимчасовий

\footnotetext{
19 Александренко О.В. Криміналістичні проблеми подолання протидії розслідуванню : дис. ... канд. юрид. наук : 12.00.09. Київ, 2004. С. 87.

${ }^{20}$ Ромців О.І. Особливості подолання протидії під час розслідування злочинів у сфері службової діяльності : дис. ... канд. юрид. наук : 12.00.09. Львів, 2016. С. 132.
} 
доступ до речей і документів; тимчасове вилучення майна; арешт майна) ${ }^{21}$. У контексті дослідження питання подолання тиску на учасників кримінального провадження нас цікавлять лише окремі з них. Однак це не виключає успішного використання під час подолання протидії судовому розгляду всіх інших.

Ефективність застосування запобіжних заходів щодо обвинуваченого беззаперечно $є$ ефективним засобом подолання протидії у вигляді тиску на учасників кримінального провадження, адже великий обсяг такої небезпеки виходить саме від особи, котра обвинувачується у вчиненні злочину, та від осіб, що їм сприяють. Метою їх застосування відповідно до п. 3 ч. 1 ст. 177 КПК України і є запобігання спробам незаконно впливати на потерпілого, свідків, іншого підозрюваного, обвинуваченого, експерта, спеціаліста у цьому ж кримінальному провадженні. Найсуворішими запобіжними засобами є тримання під вартою та домашній арешт (ст. 176, п. 3 ч. 1 ст. 177 КПК України), але, обираючи їх, слід враховувати приписи ч. 3 ст. 176 КПК України, відповідно до яких слідчий суддя, суд відмовляє у застосуванні запобіжного заходу, якщо слідчий, прокурор не доведе, що встановлені під час розгляду клопотання про застосування запобіжних заходів обставини є достатніми для переконання, що жоден із більш м'яких запобіжних заходів, передбачених ч. 1 цієї статті, не може запобігти доведеним під час розгляду ризику або ризикам.

Обираючи обвинуваченому запобіжний захід, не пов'язаний із триманням під вартою, суд може покласти на особу певні обов'язки (не відлучатися з певного населеного пункту, утримуватися від спілкування 3 конкретною особою, не відвідувати певні місця, носити електронний засіб контролю тощо (ч. 5, 6 ст. 194 КПК України)).

Досить ефективними 3 погляду подолання тиску на учасників кримінального провадження $\epsilon$ : тимчасове обмеження в користуванні спеціальним правом і відсторонення від посади. Ст. 148 КПК України, яка регламентує запровадження такого заходу, прямо вказує на те, що застосовується він у випадках перешкоджання кримінальному провадженню. Під час судового розгляду кримінального провадження такий захід забезпечення може бути застосовано лише за клопотанням сторін.

Так, як і тимчасове обмеження в користуванні спеціальним правом, відсторонення від посади (ст. 154 КПК України) застосовується 3 метою досягнення дієвості кримінального провадження. За правилами п. 6 ч. 2 ст. 155 КПК України про виклад обставин, які дають підстави вважати, що підозрюваний, обвинувачений, перебуваючи на посаді, незаконними

\footnotetext{
21 Гумін О.М. Система заходів забезпечення кримінального провадження за новим кримінальним процесуальним кодексом України. Науковий вісник НАВСУ. 2013. № 1. С. 229.
} 
засобами впливатиме на свідків та інших учасників кримінального провадження, слідчий має зазначити у клопотанні, з яким звертається до слідчого судді.

Але під час обрання заходів забезпечення кримінального провадження (зокрема запобіжних заходів, накладення арешту на майно тощо), слід враховувати, що звернення до суду з клопотанням про застосування таких заходів без передбачених законом підстав саме по собі може вказувати на спроби здійснення в такий спосіб тиску на підозрюваного, обвинуваченого у справі з боку правоохоронних органів задля досягнення певного компромісу в ході розслідування кримінального провадження. Звідси (відповідно до ч. 3 ст. 132 КПК України) застосування заходів забезпечення кримінального провадження не допускається, якщо слідчий, прокурор не доведе, що: 1) існує обгрунтована підозра щодо вчинення кримінального правопорушення такого ступеня, що може бути підставою для застосування заходів забезпечення кримінального провадження; 2) потреби досудового розслідування виправдовують такий ступінь втручання у права і свободи, про який ідеться в клопотанні слідчого, прокурора; 3) може бути виконане завдання, для виконання якого слідчий, прокурор звернеться із клопотанням. Тому з метою недопущення тиску на учасників кримінального провадження в такий спосіб слідчий суддя (під час розгляду клопотання про застосування заходів забезпечення кримінального провадження) повинен ретельно перевіряти і досліджувати зазначені обставини. На підтвердження наведемо приклад із практики Апеляційного суду Дніпропетровської області у справі № 200/5995/15-к. Так, слідчий звернувся до суду з клопотанням про обрання запобіжного заходу стосовно підозрюваного у вигляді тримання під вартою, обгрунтовуючи підозру лише: а) рапортами оперативних працівників (що $\epsilon$ недопустимими доказами (виділено нами - O. О., Р. М.)); б) поясненнями самого підозрюваного. За результатами розгляду апеляційної скарги сторони захисту, ухвалу слідчого судді було скасовано та відмовлено слідчому у задоволенні клопотання про застосування запобіжного заходу. Більше того, відповідно до ч. 6 ст. 206 КПК України органу досудового розслідування було доручено провести перевірку заявлених підозрюваним у судовому засіданні фактів щодо застосування до нього насильства під час затримання та тримання під вартою 22 .

До інших процесуальних заходів, що застосовуються в межах цього ж кримінального провадження, які можуть гарантувати належний захист осіб, котрі беруть участь у кримінальному судочинстві, зокрема, належать:

\footnotetext{
22 Із досвіду практичної діяльності Р.В. Мудрецького на посаді судді Апеляційного суду Дніпропетровської області. Власний архів Р.В. Мудрецького.
} 
1) допит / впізнання у режимі відеоконференції в ході досудового розслідування (ст. 232 КПК України) та процесуальні дії у режимі відеоконференції під час судового провадження (ст. 336 КПК України); 2) допит у суді свідка, потерпілого, обвинуваченого 3 використанням технічних засобів з іншого приміщення чи в інший спосіб, що виключає ідентифікацію особи, у разі потреби - зі створенням акустичних перешкод (ч. 9 ст. 352 , ч. 2 ст. 353 , ч. 3 ст. 351 КПК України); 3) допит свідка за відсутності певного допитаного свідка (п. 5 ст. 352 КПК України); 4) допит особи, яка перебуває за кордоном, за допомогою відеоконференції або телефонної конференції в порядку міжнародної правової допомоги (ст. 567 КПК України); 5) аудіо- і відеоконтроль особи, місця, спостереження за особою або місцем, арешт, огляд і виїмка кореспонденції, зняття інформації 3 транспортних телекомунікаційних мереж та електронних інформаційних систем, обстеження публічно недоступних місць, житла, іншого володіння особи, установлення місця перебування радіоелектронного засобу тощо (ст. 258, 267-270 КПК України) $^{23}$. Крім того, до таких заходів можуть бути віднесені: 1) виділення матеріалів кримінального провадження щодо однієї 3 осіб, яка підозрюється чи обвинувачується у вчиненні злочину й погодилася на угоду (ч. 8 ст. 469 КПК України); 2) ненадання доступу до матеріалів кримінального провадження щодо застосування заходів безпеки або видалення таких відомостей із матеріалів кримінального провадження (ч. 5 ст. 290 КПК України $)^{24}$.

Але у разі застосування засобів, що передбачають необхідність забезпечити конфіденційність даних про особу, яка сприяє правосуддю (виключення ідентифікуючих ознак особи чи їх зміну, а також допит осіб за відсутності учасників процесу тощо), обов'язково повинні бути прийняті необхідні заходи щодо запобігання фальсифікації доказів у провадженні, що в майбутньому може привести до визнання їх недійсними. Також необхідно забезпечити можливість обвинуваченому допитувати свідків обвинувачення або вимагати, щоб їх допитали, а також вимагати виклику й допиту свідків захисту на тих самих умовах, що і свідків обвинувачення, що передбачено пунктом d) ч. 2 ст. 6 Конвенції про захист прав людини й основоположних свобод.

\footnotetext{
${ }^{23}$ Касько В.В., Орлеан А.М. Забезпечення безпеки учасників кримінального провадження щодо торгівлі людьми. Київ : «ВАІТЕ», 2012. С. 18-19.

24 Козій В. Виділення матеріалів досудового розслідування як захід забезпечення безпеки підозрюваного в кримінальному провадженні. Jurnalul juridic national teorie si practica. 2015. № 2 (12). C. $137-138$.
} 


\section{3. Позапроцесуальні заходи подолання тиску на учасників кримінального провадження}

Оскільки, як вже зазначалося, основною формою протидії нині є вплив у будь-якій формі з боку злочинців, їх оточення, інших зацікавлених осіб на потерпілих, свідків, інших учасників кримінального судочинства, то ефективним буде попередження такого впливу шляхом забезпечення безпеки останніх. Здійснення заходів безпеки поза межами кримінального провадження, що розглядається, i вказує на їх позапроцесуальний характер. На необхідності застосування заходів забезпечення безпеки учасників кримінального судочинства неодноразово наголошувалося у Постановах Пленуму Верховного Суду України (далі - ППВСУ). Зокрема, у п. 13 ППВСУ «Про незалежність судової влади» від 13 червня 2007 р. № $8^{25}$ зазначено, що безпека осіб, які беруть участь у кримінальному судочинстві, є важливим засобом попередження втручання у здійснення правосуддя. Більше того, забезпечення безпеки учасників кримінального процесу $\epsilon$ одним із заходів подолання кримінальної протидії розслідуванню, тому розглядати окремо один від одного ці види діяльності неможливо $^{26}$.

Принцип необхідності забезпечити безпеку учасників кримінального судочинства поступово втілювався в життя, набував законодавчого закріплення та подальшого розвитку. Прийняття законодавчих новел свідчить про те, що учасники кримінального процесу сприймаються як особистості й громадяни зі всіма притаманними їм правами та свободами ${ }^{27}$. Нормативно-правове врегулювання проблеми подолання активного застосування незаконного тиску на осіб, котрі беруть участь у кримінальному судочинстві, забезпечується низкою нормативно-правових актів, серед яких Закони України: а) «Про забезпечення безпеки осіб, які беруть участь у кримінальному судочинстві» ${ }^{28}$; б) «Про державний захист суддів та працівників правоохоронних органів» ${ }^{29}$. Наприклад, ст. 7 Закону України «Про забезпечення безпеки осіб, які беруть участь у кримінальному судочинстві» передбачає такі заходи забезпечення безпеки учасників кримінального провадження: 1) особисту охорону, охорону

\footnotetext{
25 Про незалежність судової влади : Постанова Пленуму Верховного Суду України від 13 червня 2007 p. № 8. URL: http://zakon2.rada.gov.ua/laws/show/v0008700-07.

26 Журавлев С.Ю. Противодействие расследованию как составляющая преступной деятельности и объект научных исследований. Расследование и противодействие ему в состязательном уголовном судопроизводстве: прочессуальные и криминалистические вопросы : сборник научных трудов. Москва : Акад. управл. МВД России, 2007. С. 194.

${ }^{27}$ Тертишник В.М. Кримінально-процесуальне право України : підручник. Київ : А.С.К., 2003. С. 225.

${ }^{28}$ Про забезпечення безпеки осіб, які беруть участь у кримінальному судочинстві : Закон України від 23 грудня 1993 р. № 3782-ХІІ. Відомості Верховної Ради. 1994. № 11. С. 51.

${ }^{29}$ Про державний захист суддів та працівників правоохоронних органів : Закон України від 23 грудня 1993 р. № 3781-ХІІ. Відомості Верховної Ради. 1994. № 11. С. 50.
} 
житла і майна; 2) видавання спеціальних засобів індивідуального захисту i сповіщення про небезпеку; 3) використання технічних засобів контролю і прослуховування телефонних та інших переговорів, візуальне спостереження; 4) заміну документів і зміну зовнішності; зміну місця роботи або навчання; 5) переселення в інше місце проживання; поміщення до дошкільної виховної установи або установи органів соціального захисту населення; 6) забезпечення конфіденційності відомостей про особу; 7) закритий судовий розгляд. Проте зазначені нормативні акти, хоча i викладають основні заходи забезпечення безпеки, дещо застаріли, $\epsilon$ занадто декларативними, не містять реального механізму їх втілення та застосування, а тому потребують змін відповідно до реалій сьогодення. Слід враховувати вимоги міжнародних нормативних актів, що стосуються заходів забезпечення безпеки учасників кримінального провадження. Варто звернути увагу на досвід інших країн у вирішенні цього питання, зокрема щодо прийняття на державному рівні програми забезпечення безпеки учасників кримінального провадження та створення окремого державного органу, що забезпечує безпеку таких осіб.

Проблема захисту учасників кримінального процесу знаходиться у центрі уваги міжнародних, урядових і неурядових організацій. Міжнародні законодавчі акти, які $\epsilon$ частиною законодавства України, також передбачають необхідність забезпечення безпеки учасників кримінального судочинства. Ряд міжнародно-правових документів містить міжнародні принципи та стандарти захисту учасників кримінального судочинства. Зокрема, найбільш важливими серед них є: а) Конвенція ООН проти транснаціональної організованої злочинності 2000 р. та протоколи до неї; б) Декларація основних принципів правосуддя стосовно жертв злочинів i зловживання владою. Основні європейські стандарти у зазначеній сфері переважно сконцентровані у: а) Європейській конвенції про взаємну допомогу у кримінальних справах 1959 р. та Другому додатковому протоколі до неї 2001 р.; б) Директиві Європейського парламенту та Ради Європейського Союзу щодо встановлення мінімальних стандартів забезпечення прав, підтримання та захисту жертв злочинів від 25 жовтня 2012 р.; в) Рекомендації Rec (97) 13 Комітету міністрів Ради Свропи державам-членам щодо залякування свідків і забезпечення прав сторони захисту; г) Рекомендації Rec (2005) 9 Комітету міністрів Ради Свропи державам-членам щодо захисту свідків та осіб, які співпрацюють із 
правосуддям (останні розділи мають назви «Захист суддів і працівників кримінального правосуддя», «Захист жертв», «Захист свідків») $)^{30}$.

Рекомендації Комітету міністрів Ради Свропи Rec (97) 13 та Rec (2005) 9 чітко регулюють загальні принципи, якими керуються під час застосування заходів із захисту свідків. Комітет міністрів Ради Європи вважає неприйнятним те, що система кримінального судочинства може не доставити підсудних до суду та не отримати судове рішення у зв'язку 3 тим, що свідки відмовилися надавати правдиві та добровільні свідчення. Тому вони рекомендують, щоб кожна держава керувалася такими загальними принципами:

- необхідні законодавчі та практичні заходи мають бути прийняті для забезпечення добровільного надання свідчень і захисту свідків від будьяких посягань;

- за акти залякування свідків i близьких до них людей має передбачатися покарання як за окремий кримінальний злочин або як за складову частину злочину щодо використання незаконних погроз;

- необхідно заохочувати свідків повідомляти компетентним органам будь-яку інформацію, що стосується кримінальних злочинів, а потім давати свідчення у суді;

- працівники системи кримінального правосуддя повинні мати належну підготовку для випадків, коли свідки потребуватимуть заходів захисту, а також нормативні документи, якими слід керуватися;

- всі етапи процедур, що стосуються прийняття, здійснення, зміни та скасування заходів захисту, повинні зберігатися в таємниці; за несанкціоноване розкриття цієї інформації має передбачатися кримінальна відповідальність;

- під час здійснення заходів захисту слід також брати до уваги необхідність забезпечення належного балансу з принципом захисту прав i очікувань потерпілих ${ }^{31}$.

Вирішення проблеми забезпечення безпеки учасників кримінального судочинства залежить, зокрема, від розуміння значення таких понять, як «небезпека» та «забезпечення безпеки». Не вдаючись до детального аналізу численних варіантів визначення поняття «небезпека» та «забезпечення безпеки», зазначимо, що характерною ознакою небезпеки $є$ певна загроза конкретній особі, членам їі сім’ї, близьким родичам у зв’язку

\footnotetext{
30 Декларация основных принципов правосудия для жертв преступления и злоупотребления властью, резолюция 40/34 Генеральной Ассамблеи ООН от 29 ноября 1985 г. Международные акты о правах человека: Сборник документов. Москва : Издательская группа НОРМА-ИНФРА, 1998. С. $165-168$.

31 Семків Т. Удосконалення забезпечення безпеки осіб, які беруть участь у кримінальному провадженні. Науковий часопис Національної академї прокуратури Украӥни. 2017. № 3. C. 121. URL: http://www.chasopysnapu.gp.gov.ua/ua/pdf/3-2017/semkiv.pdf.
} 
3 можливістю позбавлення їх життя, заподіяння шкоди їхньому здоров’ю, знищення майна, належних їм житла або інших цінностей і благ ${ }^{32}$. А тому слід погодитися з М.В. Куркіним у тому сенсі, що загроза як зовнішній чинник небезпеки справляє специфічний вплив на конкретного суб'єкта процесу і завдяки цьому визначає його особливий психологічний стан ${ }^{33}$.

Поділяючи думку О.О. Зайцева $з$ приводу того, що забезпечення безпеки учасників кримінального судочинства $є$ складовою частиною державної політики, О.О.Гринків запропонував термін «забезпечення безпеки» доповнити означенням «державне» і використовувати його у судочинстві замість терміна «захист», оскільки останнім (у кримінально-процесуальній термінології) вважається надання правової допомоги (відповідно до ст. 59 Конституції України). Автор визначив «забезпечення безпеки» як виконання уповноваженими законом (компетентними) органами комплексу необхідних дій (заходів), спрямованих на недопущення можливості завдати шкоди учасникам кримінального судочинства з метою належного здійснення правосуддя ${ }^{34}$. Поділяючи таку думку, додамо, що ці заходи спрямовані не тільки на недопущення, а й на усунення вже розпочатих дій щодо створення перешкод у здійсненні правосуддя. Отже, забезпечення безпеки суб'єктів (учасників) кримінального процесу має на меті ефективне здійснення ними своїх функцій i виконання завдань судочинства $^{35}$, тобто створення необхідних умов для належного відправлення правосуддя ${ }^{36}$.

Взагалі, охорона безпеки та захист прав потерпілого як жертви злочину та свідків $\epsilon$ важливим напрямом законодавчої та правоохоронної діяльності всіх цивілізованих держав світу. Відповідно до принципу змагальності сторін у кримінальному судочинстві кримінальнопроцесуальне законодавство багатьох держав передбачає постійну присутність жертв i свідків злочинів до кінця судового розгляду кримінальних справ ${ }^{37}$.

Як нам вважається, позитивним $є$ перейняття досвіду забезпечення безпеки учасників кримінального провадження деяких зарубіжних країн. Так, у США в 1971 р. вперше в світі була введена в дію спеціальна

\footnotetext{
32 Гриньків О.О., Ляш А.О. Заходи забезпечення безпеки у кримінальному судочинстві : монографія. Тернопіль : Астон, 2012. С. 105.

${ }^{33}$ Куркін М.В. Проблеми забезпечення безпеки суб’єктів кримінального процесу : дис. ... канд. юрид. наук : 12.00.09. Харків, 1999. С. 26.

${ }^{34}$ Гриньків О.О., Ляш А.О. Заходи забезпечення безпеки у кримінальному судочинстві : монографія. Тернопіль : Астон, 2012. С. 108.

35 Лобойко Л.М. Кримінально-процесуальне право : курс лекцій. Київ : Істина, 2005. С. 99.

${ }^{36}$ Гриньків О.О., Ляш А. О. Заходи забезпечення безпеки у кримінальному судочинстві : монографія. Тернопіль : Астон, 2012. С. 122.

${ }^{37}$ Ибрагимов И.М. Зарубежные концепции защиты прав потерпевшего как жертвы преступления. Российская юстициия. 2008. № 7. С. 50.
} 
Федеральна програма захисту свідків (United States Federal Witness Protection Program), яка спочатку призначалася тільки для боротьби 3 італійською мафією, але потім, довівши свою ефективність, була поширена i на інші сфери поліцейської діяльності. Ця програма належить до компетенції Служби маршалів США, яка має свою штаб-квартиру, регіональні представництва й офіси в поліції кожного міста, де працює інспектор із питань захисту свідків. Основою системи правосуддя США стала компенсація шкоди, заподіяної внаслідок злочину, що включає не тільки прямі збитки від протиправних дій, але і понесені витрати на консультації та медичну допомогу, юридичні послуги і т. д. ${ }^{38}$. У ФРН застосовуються дві системи забезпечення безпеки свідка: довгостроковий захист, який забезпечується всіма доступними поліцейськими методами (охороною за місцем його проживання, роботи, в громадському місці й особливо в залі суду). Друга система заходів забезпечення безпеки повністю ізолює свідка від зовнішнього світу і спрямована головним чином на надання допомоги підзахисному у виборі нового місця проживання, роботи, а також в наданні необхідної матеріальної допомоги. Подібні заходи утворюють основу «нового» життя свідків після закінчення дії програми ${ }^{39}$. В Італії з 1984 р. існує спеціальна програма щодо захисту свідків, керівництво якої здійснюється Департаментом громадської безпеки Міністерства внутрішніх справ через спеціальну центральну службу захисту та Канцелярію Державного обвинувача у справах, порушених проти мафії (Prokuratore Nazionale Antimafia). Ця програма застосовується у випадках, коли заходи захисту, що вживаються відповідно до чинного законодавства Італії, виявляються недостатньо ефективними $^{40}$. У Франції координацію та керівництво всіма програмами щодо захисту осіб, котрі сприяють кримінальному судочинству, здійснює Бюро у справах жертв злочинів при Міністерстві юстиції. Крім того, в цій країні засновано Міжміністерський комітет i Національний інститут допомоги жертвам і посередництва (IHABEM), які надають допомогу та координують заходи 150 організацій і відділів, котрі підтримуються як державою, так i органами самоврядування. Щорічно Національний

\footnotetext{
${ }^{38}$ Серебрянський П.В. Порівняльно-аналітична характеристика правового регулювання застосування заходів безпеки до учасників кримінального процессу (зарубіжний досвід формування правової доктрини). Право і суспільство. 2016. № 3. С. 194.

39 Пантелеев В.А. Сравнительно-правовой анализ становления и развития института обеспечения безопасности участников уголовного судопроизводства в России и зарубежных странах Молодой ученый. 2015. № 13. C. 519. URL https://moluch.ru/archive/93/20800/ (дата обращения: 21.12.2018).

40 Федорченко А.А. Правовое положение жертвы преступления как свидетеля в международном уголовном процессе. Международное право и международные организации. International Law and International Organizations. 2014. № 1. C. 80-87. DOI: 10.7256/2226-6305.2014.1.11556.
} 
інститут сприяє захисту до 75 тис. осіб ${ }^{41}$. Законодавством Великої Британії обов'язки щодо застосування заходів безпеки у встановлених випадках покладаються на співробітників Спеціальної Служби безпеки свідків (жертв злочинів). Вони супроводжують свідків у судові інстанції, інформують їх про процесуальні рішення у справі, наприклад, про звільнення обвинуваченого під заставу, а також консультують із питань дотримання заходів безпеки ${ }^{42}$.

Незважаючи на те, що науковцями ${ }^{43}$ неодноразово вказувалося на необхідність прийняття на державному рівні Концепції вдосконалення механізму забезпечення безпеки учасників кримінального провадження, це питання залишається й дотепер до кінця не вирішеним. Президент України ще у 2002 р. давав доручення МВС, СБУ, МЗС України узагальнити світовий досвід із забезпечення безпеки потерпілих, свідків, представити пропозиції про внесення змін у Закон України «Про забезпечення безпеки осіб, які беруть участь у кримінальному судочинстві» щодо механізму реалізації його положень і фінансування відповідних заходів ${ }^{44}$. Але аналіз положень згадуваного закону свідчить про нереальність чи недостатню ефективність багатьох передбачених законодавством заходів захисту i дотепер $^{45}$. Залишається законодавчо неврегульований механізм реалізації вказаних заходів безпеки, немає достатніх практичних навичок, відсутнє належне фінансування ${ }^{46}$. До того ж, заходи безпеки здійснюються на примітивному рівні - охорона житла чи самого учасника кримінального процесу під час досудового слідства, переселення його до родичів або знайомих. Ці заходи зазвичай нетривалі й не можуть повною мірою забезпечити справжню безпеку учаснику процесу ${ }^{47}$. Прикрим прикладом неефективності таких засобів безпеки стали резонансні злочини останніх років - вбивства журналіста «Української правди» Павла Шеремета, екс-

41 Рекомендуемые виды практики в области защиты свидетелей при производстве по уголовным делам, касающимся организованной преступности. URL: http: www.unodc.org/documents/organizedcrime/ Witness-protection-manual-Feb08.pdf.

42 Краснова К.А.Защита свидетелей в государствах-членах ЕС. Российское право: образование, практика, наука. 2015. № 2 (86). С. 47.

43 Пашков С.М. Організаційно-правові засади діяльності судової міліції по забезпеченню безпеки осіб, які беруть участь у кримінальному судочинстві : автореф. дис. ... канд. юрид. наук : 12.00.07. Ірпінь, 2008. 20 с.; Качмар Б.М. Щодо підстав вжиття заходів забезпечення безпеки у кримінальному провадженні та обставин, що враховуються при цьому. Науковий вісник публічного та приватного права. 2016. № 3. C. 242-246.

44 Про заходи щодо подальшого зміцнення правопорядку, охорони прав і свобод громадян : Указ Президента України № 143 від 18 лютого 2002 р. Державний вісник Украӥни. 2002. № 5. С. 22-24.

45 Александренко О.В. Криміналістичні проблеми подолання протидії розслідуванню : дис. ... канд. юрид. наук : 12.00.09. Київ, 2004. С. 105.

46 Бахин В.П. Криминалистика. Проблемы и мнения (1962-2002). Київ : Охрана труда. 2002. C. 234-235.

${ }^{47}$ Гарник М. Проблеми захисту прав потерпілих від злочину. Вісник прокуратури. 2002. № 3. С. 4. 
депутата Держдуми Росії Дениса Вороненкова, учасниці бойових дій на Донбасі Аміни Окуєвої та ін. ${ }^{48}$.

Враховуючи такі резонансні події та потреби сьогодення, у Верховній Раді України зареєстровано законопроект № 8457 від 08 червня 2018 р. «Про забезпечення безпеки осіб, які беруть участь у кримінальному судочинстві», який має вирішити викладені проблеми ${ }^{49}$. Як зазначено у пояснювальній записці до нього, у 2017 р. в Україні здійснювалися довготривалі заходи захисту стосовно близько 300 осіб (понад чверть із них $\epsilon$ не свідками, а працівниками суду або правоохоронних органів). Сучасний стан захисту свідків в Україні характеризується тим, що у структурі майже кожного правоохоронного органу України функціонує спецпідрозділ, який займається захистом свідків: Національна поліція, СБУ, НАБУ, Державне бюро розслідувань. На практиці фізична особиста охорона не убезпечує від збройних нападів у людних місцях, підривів автомобіля чи місця проживання свідка або потерпілого. Законопроектом пропонується на законодавчому рівні вирішити питання про встановлення взаємних прав та обов'язків між особою, взятою під захист, та органом, що здійснює заходи із забезпечення безпеки, їх закріплення та відповідальність за їх невиконання.

Функція забезпечення безпеки осіб, які беруть участь у кримінальному судочинстві, має зосереджуватися в єдиному правоохоронному органі Національній службі захисту свідків і потерпілих. Залежно від характеру та природи загроз можуть бути застосовані програми захисту першого або другого ступенів. Програма захисту першого ступеня здійснюється відповідно до підслідності кримінальних правопорушень правоохоронними органами. Програма захисту другого ступеня має здійснюватися Національною службою захисту та вирішувати завдання щодо забезпечення безпеки осіб, які беруть участь у кримінальних провадженнях щодо злочинів проти основ національної безпеки України, тяжкі чи особливо тяжкі злочини, вчинені організованими групами чи злочинними організаціями, злочини проти миру, безпеки людства та міжнародного правопорядку, а також про корупційні правопорушення, учинені державними службовцями категорії А.

Звернемо увагу й на те, що окрім органів, які здійснюють заходи забезпечення безпеки, в Законі доцільно чітко визначити й коло органів, що мають приймати рішення про застосування таких заходів $\mathrm{i}$ ïx повноваження. Так, ознайомлення $з$ текстом згадуваного Законопроекту дозволяє констатувати, що він не передбачає суд як орган, котрий їх

\footnotetext{
48 Закон - щит для свидетеля или иллюзия. URL: https://ukr.segodnya.ua/ukraine/zakon-okuevoy-shchitdlya-svidetelya-ili-illyuziya-1183882.html.

49 Про забезпечення безпеки осіб, які беруть участь у кримінальному судочинстві : законопроект № 8457 від 08 червня 2018 p. URL: http://w1.c1.rada.gov.ua/pls/zweb2/webproc4_1?pf3511=64189.
} 
приймає (ст. 4). Така позиція законодавця є незрозумілою і ставить під сумнів здатність забезпечити правовий режим застосування заходів безпеки, адже до них належать і оперативно-розшукові заходи (ст. 8 Законопроекту), в т. ч. й ті, що пов'язані з тимчасовим обмеженням прав $\mathrm{i}$ свобод людини. Більше того, в цьому проглядається й певна непослідовність, оскільки відповідно до положень Закону України «Про оперативно-розшукову діяльність», а також КПК України (глава 21), оперативно-розшукові заходи, негласні слідчі (розшукові дії), у випадках, передбачених КПК України, проводяться на підставі ухвали слідчого судді (виділено нами - O. O., Р. М.), постановленої за клопотанням прокурора або слідчого, погодженого 3 прокурором. 3 огляду на наведене, на наш погляд, цілком логічно у ст. 4 Законопроекту передбачити судовий контроль у прийнятті рішення про забезпечення безпеки особи.

Законопроектом також пропонується створення програми захисту, що визначається як комплекс заходів безпеки відповідного ступеня, що застосовуються органом, який забезпечує безпеку, 3 метою заохочення учасників кримінального провадження й осіб, котрі надають допомогу в запобіганні і протидії корупції (викривачів), до активної співпраці 3 правосуддям, спрямованих на захист життя, здоров'я, страхування житла та майна цих осіб, їх близьких родичів і членів сімей від протиправних посягань.

Проте реальна дія такої законодавчої ініціативи залежить не тільки від регламентації процедури прийняття рішення та застосування заходів безпеки, що, безумовно, є кроком уперед у проблемному питанні, а й від створення передумов для виконання того механізму, що буде визначений законом. Як наголошує О.О. Зайцев, організація державного захисту учасників кримінального судочинства передбачає вирішення концептуальних питань управлінського характеру, ресурсного та інформаційного забезпечення, без чого неможлива їх практична реалізація ${ }^{50}$. На нашу думку, позитивний результат залежить від створення дійсно незалежного окремого органу, який здійснюватиме заходи щодо забезпечення безпеки учасників кримінального провадження; створення державної програми 3 цього питання, що відповідатиме найкращим міжнародним стандартам; чіткого розмежування повноважень органів, які будуть приймати рішення про забезпечення безпеки та виконувати вказані рішення.

\section{ВИСНОВКИ}

Таким чином, подолання тиску на учасників кримінального провадження та забезпечення їх безпеки є одним із пріоритетних завдань держави у сфері правосуддя, яке потребує невідкладного комплексного

\footnotetext{
C. 109.

${ }^{50} 3$ айцев О.А. Государственная защита участников уголовного процесса. Москва : Экзамен, 2002.
} 
вирішення. 3 урахуванням проведеного нами дослідження можна констатувати, що 3 метою подолання тиску на учасників кримінального провадження під час судового розгляду необхідне застосування комплексних заходів. Такими $є$ кримінально-правові, кримінальнопроцесуальні та позапроцесуальні (організаційно-тактичні) заходи.

Кримінально-правові заходи подолання тиску на учасників кримінального судочинства спрямовані на припинення, усунення та нейтралізацію протидії з боку зацікавлених осіб. Вони закріплюють ознаки складу конкретних злочинних діянь, які по суті $\epsilon$ різними видами (формами) протидії, i визначають об’єктивну сторону цього діяння, суб'єкта і суб'єктивну сторону.

Кримінально-прочесуальні заходи подолання тиску на учасників кримінального судочинства застосовуються 3 метою досягнення дієвості цього провадження шляхом застосування заходів забезпечення кримінального провадження та інших процесуальних заходів у межах цього ж кримінального провадження, які передбачають особливий порядок його провадження чи особливий порядок вчинення окремих процесуальних дій для забезпечення подолання тиску на учасників кримінального провадження.

Позапроцесуальні заходи подолання тиску на учасників кримінального провадження спрямовані на застосування заходів безпеки до потерпілих, свідків, інших учасників кримінального судочинства 3 метою подолання на них впливу у будь-якій формі з боку злочинців, їх оточення, інших зацікавлених осіб.

Національне законодавство з цього питання потребує вдосконалення 3 урахуванням міжнародних стандартів, результатом чого має бути створення власної системи для захисту учасників кримінального провадження від протиправного на них впливу.

\section{АНОТАЦІЯ}

У статті розглянуто особливості подолання тиску на учасників кримінального провадження під час судового розгляду. Констатовано, що здійснення тиску зацікавленими особами на свідків, потерпілих та інших учасників кримінального судочинства не лише спрямоване на заподіяння останнім будь-якої шкоди, а й грунтується на досягненні головної мети схилити їх до відмови давати показання або іншим чином завадити, припинити сприяння правосуддю чи помститися за вже здійснене сприяння.

Проаналізовано складники системи протидії в частині подолання тиску на учасників кримінального судочинства, які систематизовано на кримінальноправові, кримінально-процесуальні та позапроцесуальні (організаційнотактичні) заходи. Кримінально-правові заходи подолання тиску на учасників 
кримінального судочинства спрямовані на припинення, усунення та нейтралізацію протидії з боку зацікавлених осіб. Кримінально-процесуальні заходи спрямовані на забезпечення кримінального провадження шляхом застосування заходів забезпечення та інших процесуальних заходів у межах цього ж кримінального провадження. Позапроцесуальні заходи спрямовані на забезпечення безпеки учасників кримінального провадження, що, зокрема, передбачає: а) здійснення оперативно-розшукових заходів; б) особливий склад осіб, якими приймається рішення про їх застосування та реалізацію; в) здійснення таких заходів поза межами провадження, що проводиться у кримінальному провадженні.

Визначено шляхи оптимізації заходів, які застосовуються 3 метою подолання тиску на учасників кримінального провадження. Зокрема, пропонується створення спеціальної програми захисту, що визначається як комплекс заходів безпеки відповідного ступеня, які застосовуються органом, котрий забезпечує безпеку учасників кримінального провадження, спрямованих на захист життя, здоров’я, страхування житла та майна цих осіб, їх близьких родичів і членів сімей від протиправних посягань.

\section{ЛIТЕРАТУРА}

1. Трухачев В.В. Криминалистический анализ сокрытия преступной деятельности. Воронеж : Изд-во Воронеж. гос. ун-та, 2000. 396 с.

2. Біленчук П.Д., Луговий I.О. Способи протидії злочинних угруповань діяльності правоохоронних органів у розслідуванні злочинів. Науковий вісник Нац. акад. внутр. справ Украӥни. 2003. № 1. С. 195-200.

3. Новикова М.В. Обеспечение безопасности участников уголовного судопроизводства как гарантия осуществления правосудия в современных условиях : автореф. дис. ... канд. юрид. наук : 12.00.09. Екатеринбург, 2006. 23 c.

4. Габро O.I., Карпов Н.С. Державний захист та забезпечення безпеки осіб, які беруть участь у судочинстві, за законодавством України . Боротьба з організованою злочинністю $і$ корупцією (теорія і практика) / Міжвідомчий науково-дослідний центр 3 проблем боротьби 3 організованою злочинністю. Київ, 2007. № 17. С. 254-266.

5. Озерський I.В. Кримінальний процес України : навчальний посібник / Міністерство освіти і науки України. Київ : МАУП, 2003. 400 с.

6. Академічний тлумачний словник української мови. URL: http://sum.in.ua/s/tysk.

7. Бортик. Убивство адвоката. URL: https:/uiamp.org.ua/bortnikubiystvo-advokata-grabovskogo-politicheskoe; https://www.unian.net/society/ 10197798-svetit-pozhiznennoe-podozrevaemomu-v-ubiystve-advokatanozdrovskoy-izmeneno-ranee-obyavlennoe-podozrenie.html. 
8. Дело милицейских оборотней. Газета «Правда». URL: https://www.pravda.com.ua/articles/2007/03/28/3220974/; https://racurs.ua/259miliceyskie-oborotney-delo.html.

9. Рекомендація No Rec (2005) 9 Комітету міністрів Ради Свропи державам-членам щодо захисту свідків та осіб, які співпрацюють 3 правосуддям URL: http://scourt.gov.ua/clients/vsu/vsu.nsf/(documents)/ 7442A47EB0B374B9C2257D8700495F8B.

10. Александренко О.В. Криміналістичні проблеми подолання протидії розслідуванню : автореф. дис. ... канд. юрид. наук : 12.00.09. Київ, 2004. $20 \mathrm{c}$.

11. Касько В.В., Орлеан А.М. Забезпечення безпеки учасників кримінального провадження щодо торгівлі людьми. Київ : «ВАITЕ», 2012. $50 \mathrm{c}$.

12. Бабаева Э.У. Противодействие предварительному расследованию и пути его преодоления. Москва : Щит-М, 2001. 162 с.

13. Александренко О.В. Криміналістичні проблеми подолання протидії розслідуванню : дис. ... канд. юрид. наук : 12.00.09. Київ, 2004. 192 с.

14. Бабаева Э.У. Проблемы теории и практики преодоления противодействия уголовному преследованию : монография. Москва : Юрлитинформ, 2010. 280 с.

15. Большой энциклопедический словарь / гл. ред. А.М. Прохоров. Москва : Большая Российская энциклопедия; Санкт-Петербург : Норинт, 1998. C. 785.

16. Ромців О.І. Особливості подолання протидії під час розслідування злочинів у сфері службової діяльності : дис. ... канд. юрид. наук : 12.00.09. Львів, 2016. 232 с.

17. Гумін О.М. Система заходів забезпечення кримінального провадження за новим кримінальним процесуальним кодексом України. Науковий вісник НАВСУ. 2013. № 1. С. 226-231.

18. Козій В. Виділення матеріалів досудового розслідування як захід забезпечення безпеки підозрюваного в кримінальному провадженні. Jurnalul juridic national teorie si practica. 2015. № 2 (12). C. 135-138.

19. Про незалежність судової влади: Постанова Пленуму Верховного Суду України від 13 червня 2007 р. № 8: URL: http://zakon2.rada.gov.ua/ laws/show/v0008700-07.

20. Журавлев С.Ю. Противодействие расследованию как составляющая преступной деятельности и объект научных исследований. Расследование и противодействие ему в состязательном уголовном судопроизводстве: прочессуальные и криминалистические вопросы : сборник научных трудов. Москва : Акад. управл. МВД России, 2007. С. 194-195.

21. Тертишник В.М. Кримінально-процесуальне право України : підручник. Київ : А.С.К., 2003. 1119 с. 
22. Про забезпечення безпеки осіб, які беруть участь у кримінальному судочинстві : Закон України від 23 грудня 1993 р. № 3782-XII. Biдомості Верховної Ради. 1994. № 11. Ст. 51.

23. Про державний захист суддів та працівників правоохоронних органів : Закон України від 23 грудня 1993 р. № 3781-XII. Biдомості Верховної Ради. 1994. № 11. Ст. 50.

24. Декларация основных принципов правосудия для жертв преступления и злоупотребления властью, резолюция 40/34 Генеральной Ассамблеи ООН от 29 ноября 1985 г. Международные акты о правах человека: Сборник документов. Москва : Издательская группа НОРМАИНФРА, 1998. С. 165-168.

25. Семків Т. Удосконалення забезпечення безпеки осіб, які беруть участь у кримінальному провадженні. Науковий часопис Наміональної академії прокуратури України. 2017. № 3. С. 119-128. URL: http://www.chasopysnapu.gp.gov.ua/ua/pdf/3-2017/semkiv.pdf.

26. Гриньків О.О., Ляш А.О. Заходи забезпечення безпеки у кримінальному судочинстві : монографія. Тернопіль : Астон, 2012. 260 с.

27. Куркін М.В. Проблеми забезпечення безпеки суб'єктів кримінального процесу : дис. ... канд. юрид. наук : 12.00.09. Харків, 1999. $161 \mathrm{c}$.

28. Лобойко Л.М. Кримінально-процесуальне право : курс лекцій. Київ : Істина, 2005. 456 с.

29. Ибрагимов И.М. Зарубежные концепции защиты прав потерпевшего как жертвы преступления. Российская юстииия. 2008. № 7. C. $50-57$.

30. Серебрянський П.В. Порівняльно-аналітична характеристика правового регулювання застосування заходів безпеки до учасників кримінального процесу (зарубіжний досвід формування правової доктрини). Право і суспільство. 2016. № 3. С. 193-198.

31. Пантелеев В.А. Сравнительно-правовой анализ становления и развития института обеспечения безопасности участников уголовного судопроизводства в России и зарубежных странах Молодой ученый. 2015. № 13. C. 518-521. URL: https://moluch.ru/archive/93/20800/ (дата обращения: 21.12.2018).

32. Федорченко А.А. Правовое положение жертвы преступления как свидетеля в международном уголовном процессе. Международное право и международные организачии. International Law and International Organizations. 2014. № 1. C. 80-87. DOI: 10.7256/2226-6305.2014.1.11556.

33. Рекомендуемые виды практики в области защиты свидетелей при производстве по уголовным делам, касающимся организованной преступности. URL: http: www.unodc.org/documents/organizedcrime/Witnessprotection-manual-Feb08.pdf. 
34. Краснова К.А. Защита свидетелей в государствах-членах ЕС. Российское право: образование, практика, наука. 2015. № 2 (86). С. 46-49.

35. Пашков С.М. Організаційно-правові засади діяльності судової міліції по забезпеченню безпеки осіб, які беруть участь у кримінальному судочинстві : автореф. дис. ... канд. юрид. наук : 12.00.07. Ірпінь, 2008. $20 \mathrm{c}$.

36. Качмар Б.М. Щодо підстав вжиття заходів забезпечення безпеки у кримінальному провадженні та обставин, що враховуються при цьому. Науковий вісник публічного та приватного права. 2016. № 3. С. 242-246.

37. Про заходи щодо подальшого зміцнення правопорядку, охорони прав і свобод громадян : Указ Президента України № 143 від 18 лютого 2002 р. Державний вісник України. 2002. № 5. С. 22-24.

38. Бахин В.П. Криминалистика. Проблемы и мнения (1962-2002). Київ : Охрана труда, 2002. 268 с.

39. Гарник М. Проблеми захисту прав потерпілих від злочину. Вісник прокуратури. 2002. № 3. С. 3-5.

40. Закон - щит для свидетеля или иллюзия. URL: https://ukr.segodnya.ua/ukraine/zakon-okuevoy-shchit-dlya-svidetelya-iliillyuziya-1183882.html.

41. Про забезпечення безпеки осіб, які беруть участь у кримінальному судочинстві : законопроект № 8457 від 08 червня 2018 p. URL: http://w1.c1.rada.gov.ua/pls/zweb2/webproc4_1?pf3511=641899.

42. Зайцев О.А. Государственная защита участников уголовного процесса. Москва : Экзамен, 2002. 512 с.

\section{Information about authors:} Oderiy O. V.,

Doctor of Law, Associate Professor, Professor at the Department of Criminal Law Disciplines and Judicial Expertise of the Donetsk Law Institute of the Ministry of Internal Affairs of Ukraine 21, Stepan Tilga str., Kryvyi Rih, Dnipropetrovsk region, Ukraine

Mudretskiy R. V.,

Candidate for a degree in the Candidate Legal Sciences of the Department of Criminal Law Disciplines and Judicial Expertise of Donetsk Law Institute of the Ministry of Internal Affairs of Ukraine 21, Stepan Tilga str., Kryvyi Rih, Dnipropetrovsk region, Ukraine, Judge of the Court of Appeal of Dnipropetrovsk 13, Kharkivska str., Dnipro, Ukraine 